\title{
Seroprevalence of Avian Influenza Virus Subtype H5 among Poultry Workers of Central Traditional Markets in Indonesia
}

\author{
Dina Novitasari and Chairul Anwar* \\ Department of Veterinary Anatomy, Faculty of Veterinary Medicine, Universitas Airlangga, Surabaya, East Java, Indonesia.
}

*Corresponding author`s Email: chairulhisto@gmail.com; ORCID: 0000-0002-3309-5291

Received: 04 Nov. 2020

Accepted: 18 Dec. 2020

\begin{abstract}
Avian Influenza (AI) has been spread rapidly in almost all the provinces of Indonesia by the end of 2007, and it has become endemic. Avian Influenza viruses can be infecting to human from direct or indirect contact with the infected or dead poultry, and a visit to the wet poultry market in the neighborhood. Seroprevalence studies can be used to identify the clinical key, epidemiological studies, and the spread of AI viruses in humans. The aim of present study was to investigate the seroprevalence of Avian Influenza (AI) virus, subtype H5 among poultry workers at the central traditional market in industrial. To meet the mentioned demand, 26 blood samples were collected from the poultry workers via the median cubital vein. The antibody titer was examined using Hemagglutination Inhibition (HI) assay using H5 antigen from duck licensed under A/Dk/Indonesia/AU-78/12 (H5N1) and three kinds of red blood cells taken from horse, chicken and guinea pig. The serum samples were added with Receptor Destroying Enzyme (RDE) with a ratio of $3: 1(\mathrm{v} / \mathrm{v})$ for an overnight, and pretreated with $10 \%$ of red blood cells before the HI assay was conducted. Based on the findings, it can be concluded that the percentage of seroprevalence of Avian Influenza (AI) virus, subtype $\mathrm{H} 5$ among poultry workers at central traditional market was $0 \%$. Thirteen samples showed a negative result of the HI test. All of the workers' blood serum obtained less than $2^{4}$ antibody titer from the HI test. As the results showed, the research on the poultry workers in the traditional market was carried out, and it obtained negative results; all the workers were not infected with the Avian Influenza virus. In other words, Avian Influenza is not meaningful in poultry farm workers in Sidoarjo suburb traditional farms.
\end{abstract}

Key words: Avian Influenza, Poultry workers, Seroprevalence, Traditional market.

\section{INTRODUCTION}

Avian influenza (AI), H5N1 is one of the respiratory diseases which commonly affected poultry caused by an influenza virus from the Orthomyxovirida family; the virus can also be transmitted to human (Al-Natour and Abo-Shehada, 2005; Wang and Alexander, 2021). The epidemic spread of avian influenza, H5N1 in Indonesia occurred in Java in August 2003 affected birds, which led to the spread of the disease to other areas of south east Asia (Gutiérrez et al., 2009). By the end of 2005, the disease was considered endemic in parts of Java, Sumatra, Kalimantan, Sulawesi, and Bali (Santhia et al., 2009). The first zoonotic transmission was confirmed in western Java in July 2005 (Wiyono et al., 2004; Takano et al., 2009). From then on, a total of 199 human H5N1 cases have been reported, in which 167 were fatal (WHO, 2014). Avian Influenza virus in Indonesia is attributed to $\mathrm{H} 5 \mathrm{~N} 1$ virus clade 2.1.3 and 2.3.2 (WHO, 2014).
Many researchers have been investigating the spread of AI virus on livestocks, poultry workers, farmers, and their family. Based on the previous study, it was found that influenza A viruse (H5N1) were spread among pigs, and gradually adapted themselves to recognize human-type receptors, affecting farmers, workers, and their families in the farm area to have a great risk of being infected or contaminated with the new viruses (Frederika et al., 2013; Lailirahmawati et al., 2015). The fatality rate of $\mathrm{H} 5 \mathrm{~N} 1$ was less than the frequent rate reported more than $50 \%$. Although it is impossible to determine $\mathrm{H} 5 \mathrm{~N} 1$ fatality rate accurately, it could be assumed that $1 \%$ to $2 \%$ infection rate would translate a large amount of infection in exposed (Wang et al., 2012).

Avian Influenza viruses may be transmitted to human, through direct or indirect contact with the infected or dead poultry, and a visit to wet and non-cleaned poultry markets. The viruses are normally prevented or at least controlled by an immune defense; If the viruses 
transferred in invading the body and overcoming the immune defenses, they may cause the disease. The viruses will survive and have sufficient time to replicate and transmit the progeny to their host (Xu et al., 2009). Seroprevalence studies have been conducted in Thailand, Cambodia, Vietnam (Dung et al., 2014), and Indonesia (Robert et al., 2010) to evaluate the clinical and epidemiological factors, and other key points related to human influenza A infections (H5N1) in 2011 (Dung et al., 2014).

The researcers were interested to investigate the sero-prevalence of Avian Influenza (AI) virus subtype H5 among poultry workers at a central traditional market in an industrial city in suburb of Sidoarjo. Therefore, the purpose of current study was to investigate the seroprevalence of Avian Influenza (AI) virus subtype H5 whose main habitual activities revolve around poultries in an industrial city's and especially in its central traditional markets.

\section{Ethical approval}

The Universitas Airlangga Ethics Committee, Airlangga, approved the employed protocol after the agreement of local health authorities for all participants.

\section{MATERIALS AND METHODS}

\section{Collection and the storage procedure of poultry workers' blood serum and red blood cells of horse, guinea pig, and chicken}

The blood sample of the workers who worked in the poultry market was taken using an incidental sampling method (Mohsin, 2016).

This research was conducted in a Biosafety Level-2 (BSL-2) laboratory in Avian Influenza Research Center (AIRC), Universitas Airlangga of Indonesia. Implementation of the present research was carried out from February to April 2017. The materials that were used in this research were 26 blood serums from the workers in Larangan Sidoarjo traditional market. The experimental laboratory components were including; duck's AI antigen subtype H5 A/Dk/Indonesia/AU-78/12 (H5N1) from Avian Influenza Research Center (AIRC), $1 \%$ and $10 \%$ horse Red Blood Cell (RBC), $0.5 \%$ and $10 \%$ chicken Red Blood Cell (RBC), $0.75 \%$ and $10 \%$ guinea pig Red Blood Cell (RBC), Phosphate Buffered Saline (PBS) solution, Receptor Destroying Enzyme (RDE) (II) "Seiken" (Denka Seiken Co., Ltd, Tokyo, Japan), physiological saline $0.9 \%$, and alcohol $70 \%$.
Red blood cells used for Hemagglutinin (HA) and Hemagglutinin Inhibition (HI) assay in the current research were taken from horse, chicken, and guinea pig which were collected from cephalic (horse), brachial (chicken), and intracardiac vein (guinea pig) using a syringe, and then were placed into a vacutainer tube with Ethylene Diaminetetra Acetic Acid (EDTA). The preparations of packed RBCs were first started by carefully collecting $3-5 \mathrm{ml}$ blood to be placed into the conical tube by the volume of $15 \mathrm{ml}$, then filled with cold PBS, and mixed gently by inversion. The mix of RBCs and PBS were centrifuged at $3000 \mathrm{rpm}$ for 5 minutes at $4^{\circ} \mathrm{C}$, in which the supernatant was aspirated carefully to not disturb the pellet of RBCs. The conical tube was filled gently with cold PBS again, and the process was repeated carefully for three PBS washes to prevent hemolysis.

On the other hand, Receptor Destroying Enzyme (RDE) treatment was given to remove nonspecific virus inhibitor, which would cause a false positive result in HI assay. First, a vial of RDE (II), Seiken, was reconstituted with $20 \mathrm{ml}$ of $0.9 \%$ saline. Three parts of RDE were added to one part of serum (e.g. $20 \mu 1$ serum $+60 \mu \mathrm{l}$ RE), then vortexed for homogenization. The RDE-serum mixtures were incubated at $37^{\circ} \mathrm{C}$ for $18-20$ hours (overnight) in a dry bath, and then heated in a $56^{\circ} \mathrm{C}$ dry bath for 30 minutes to inactivate the RDE. Following after, the serum was allowed to cool in a room temperature. The $10 \mathrm{ml}$ of RBCs in blood samples of horse, chicken or guinea pig was absorbed (packed RBCs) according to the procedure to remove the nonspecific agglutinin (WHO, 2013). One part of RBCs $10 \%$ was combined with one part of treated serum (e.g. $20 \mu 1$ serum $+60 \mu 1 \mathrm{RDE}+80 \mu 1 \mathrm{RBCs} 10 \%$ ). It was mixed thoroughly and incubated at room temperature for 30 minutes, then inverted gently to be mixed every 10 minutes. The treated serums were centrifuged at $2000 \mathrm{rpm}$ for 10 minutes at $4^{\circ} \mathrm{C}$ to pellet the erythrocytes. The serum was decanted and placed in another Eppendorf to be tested in $\mathrm{HI}$ assay, then the erythrocytes pellet was discarded (WHO, 2013; Born et al., 2019).

\section{Hemagglutinin assay and hemagglutinin inhibition assay with red blood cells of the horse, chicken, and guinea pig \\ The blood samples were taken from 24 male animals contained 4 horses, 12 chickens, and 8 guinea pigs and Hemagglutinin (HA) assay was done. The determination of HA titers of AI antigen subtype H5 (separated from animals' blood) was carried (IDVet Kit, ID Screen ${ }^{\circledR}$ Influenza H9 Elisa Antibody kit, France). The concentrate}


of red blood cells was $1 \%$, and it was put on "V-bottom" microplate (Wang et al., 2014). First, $50 \mu \mathrm{l}$ of PBS were added to 12 wells in rows A and B (control RBC). Then, $50 \mu \mathrm{l}$ of the antigen added to well A1. Serial of two-fold dilutions were made by transferring $50 \mu$ from well A1 sequentially through well A12, then $50 \mu 1$ were discarded from well A12. Fifty $\mu 1$ of $1 \%$ suspension of each kind of $\mathrm{RBC}$ was added to all wells in rows $\mathrm{A}$ and $\mathrm{B}$. The plate was tapped gently to be mixed and covered with plastic wrap, then incubated at room temperature for 60 minutes. After that, the haemagglutination assay (HA) titer was read by tilting the plate at $45^{\circ}$ to $60^{\circ}$ angle. The settled RBCs in row B (control RBC) would start running, and formed a teardrop-shape due to the gravity, and the result was positive if the erythrocytes formed a diffuse film. Antigen titer was the highest dilution of virus that still caused complete hemagglutination (Born et al., 2019).

The standard working dilution of virus must have an HA titer of eight hemagglutination units (HAU) per $50 \mu \mathrm{l}$ (as same as four HAU per $25 \mu \mathrm{l}$ ). If the working antigen did not have an HA titer of eight HAU per $50 \mu 1$, it must be adjusted accordingly to the titer of antigen by diluting the virus with PBS to decrease the number of HAU. For instance, prepared three $\mathrm{ml}$ of eight HAU per $50 \mu \mathrm{l}$ from $2^{4} \mathrm{HA}$ titer was done by adding $1.5 \mathrm{ml}$ antigen with $1.5 \mathrm{ml}$ PBS. Therefore, the diluted viruses that contained eight HAU per $50 \mu \mathrm{l}$ (or four HAU per $25 \mu \mathrm{l}$ ) must be verified by performing a second HA test/retitration (WHO, 2013). The retritration or back titration was a procedure to verify the correct units of hemagglutinin. The retitration process was carried out for each kind of red blood cells.

Besides, $\mathrm{HI}$ assay was also investigated for each kind of RBCs from horse, chicken, and guinea pig. Hemagglutinin assay in this research was used RBCs $1 \%$ and "V-bottom" microplate for each type of RBCs source was applied respectively. First, $25 \mu 1$ of PBS were added to the well number 1 to 12 . Then, $25 \mu 1$ of treated serum was added to the well number 1 , and serial of two-fold dilutions were made by transferring $25 \mu \mathrm{l}$ from the first well to the well number 10 . The final $25 \mu$ l were discarded. After that, $25 \mu \mathrm{l}$ of standardized antigens containing four HAU were added to all wells containing the serum (except well number 11 and 12), and $25 \mu 1$ of PBS was added to all wells in column number 11 to be used as RBC controls and all wells in column number 12 for serum control. The plate was tapped gently to be mixed and covered with plastic wrap, then incubated at room temperature for 30 minutes.
After that, $50 \mu \mathrm{l}$ of $1 \%$ horse RBC suspension was added to each well. The plate was tapped gently to be mixed and covered with plastic wrap, then incubated at room temperature for 60 minutes. The HI titers of the serums were recorded after the 60 minutes of incubation by tilting the plate at a $45^{\circ}$ to $60^{\circ}$ angle. The settled RBCs in column number 11 should start pulling or running, and they formed a teardrop-shape due to the gravity. Antibody titer is the reciprocal of the antiserum's highest dilution that produces complete hemagglutination inhibition. Positive antibody titer is a sample that has higher or equal titer with $2^{4}(15,18)$. The data from HI assay was presented descriptively by calculating the percentage of the antibody of AI virus subtype H5 among the workers in the poultry market.

\section{RESULTS}

Collection and storage procedure of the workers' blood serum, red blood cells of horse, guinea pig, and chicken

Based on the result of present study, 13 samples have been collected from blood serums of the workers at the Larangan traditional market in Sidoarjo, Indonesia. Red blood cells that were used for HA and HI assay in this research were from the horse, chicken and guinea pig. They were collected from the cephalic (horse), brachial (chicken), and intracardiac (guinea pig) veins. Present study succeeded in taking the samples according to the criteria of the existing procedures (WHO, 2013). All samples used in the current study were feasible and appropriate for the HA and HI test. All samples of red blood cells were collected; HA and HI assays were performed, and the data was analyzed and presented descriptively.

\footnotetext{
Hemagglutinin assay and hemagglutinin inhibition assay with the red blood cells of horse, chicken, and guinea pig

Based on the result of this study, the researchers used three different kinds of RBCs in HI test, which were from horse, guinea pig, and chicken to be compared and given a more sensitive result to detect human AI, and AI subtype H5 antigen from duck A/Dk/Indonesia/AU-78/12 (H5N1). From 13 serum samples, any evidence of positive antibodies titer was found against AI subtype H5 among the workers in the central traditional market in the industrial city of Sidoarjo, Indonesia, therefore the seroprevalence was $0 \%$ (Table 1 ).
} 
Table 1. The results of hemagglutination inhibition test for the workers on avian influenza subtype H5 using RBCs of horse, guinea pig, and chicken

\begin{tabular}{|c|c|c|c|c|c|}
\hline \multirow{3}{*}{ No. } & \multirow{3}{*}{ Serum code } & \multicolumn{3}{|c|}{ RBCs } & \multirow{3}{*}{ Statement } \\
\hline & & Horse & Guinea pig & Chicken & \\
\hline & & \multicolumn{3}{|c|}{ HI test result (antibody titer) } & \\
\hline 1 & LSR 1 & $<2^{4}$ & $<2^{4}$ & $<2^{4}$ & Negative \\
\hline 2 & LSR 2 & $<2^{4}$ & $<2^{4}$ & $<2^{4}$ & Negative \\
\hline 3 & LSR 3 & $<2^{4}$ & $<2^{4}$ & $<2^{4}$ & Negative \\
\hline 4 & LSR 4 & $<2^{4}$ & $<2^{4}$ & $<2^{4}$ & Negative \\
\hline 5 & LSR 5 & $<2^{4}$ & $<2^{4}$ & $<2^{4}$ & Negative \\
\hline 6 & LSR 6 & $<2^{4}$ & $<2^{4}$ & $<2^{4}$ & Negative \\
\hline 7 & LSR 7 & $<2^{4}$ & $<2^{4}$ & $<2^{4}$ & Negative \\
\hline 8 & LSR 8 & $<2^{4}$ & $<2^{4}$ & $<2^{4}$ & Negative \\
\hline 9 & LSR 9 & $<2^{4}$ & $<2^{4}$ & $<2^{4}$ & Negative \\
\hline 10 & LSR 10 & $<2^{4}$ & $<2^{4}$ & $<2^{4}$ & Negative \\
\hline 11 & LSR 11 & $<2^{4}$ & $<2^{4}$ & $<2^{4}$ & Negative \\
\hline 12 & LSR 12 & $<2^{4}$ & $<2^{4}$ & $<2^{4}$ & Negative \\
\hline 13 & LSR 13 & $<2^{4}$ & $<2^{4}$ & $<2^{4}$ & Negative \\
\hline
\end{tabular}

Antibody titers might be regarded as positive if there is inhibition at a serum dilution of $1 / 16$ or $\geq 24$ (OIE, 2014). LSR is a code for coding samples.

\section{DISCUSSION}

The purpose of the current study was to investigate the seroprevalence of Avian Influenza (AI) virus, subtype H5 among the workers in the central traditional poultry market of Sidoarjo, Indonesia. According to this research, none of the sample had a positive result $(0 \%)$, nor indicated the existence of AI virus even though previous investigation which revealed that the wild birds around Larangan traditional market in Sidoarjo were infected with AI virus H5N1 (Poetranto et al., 2011). Other previous research also reported that there was a report of AI virus subtype H5 in Larangan traditional market of Sidoarjo (Frederika et al., 2013; Lailirahmawati et al., 2015). Therefore, the researchers assumed that the zero seroprevalence might be due to no avian-to-human transmission yet in the central traditional market of Larangan, Sidoarjo, Indonesia.

Avian-to-human transmission is limited and rare because the species barrier is quite strong to accommodate the transmission of $\mathrm{H} 5 \mathrm{~N} 1$ virus. Through the use of lectins Maackia amurensis agglutinin (MAA) for $S A \alpha 2,3 G a l$ receptors and Sambucus nigra agglutinin (SNA) for SA 2,6Gal receptors, it was discovered that avian and human influenza viruses typically have a different SAbinding preference. Therefore, host range distribution is strongly restricted by the receptor specificity due to the surface antigen of hemagglutinin (HA) protein. Human influenza viruses bind preferentially to $S A \alpha 2,6 \mathrm{Gal}$ receptors which is dominantly located on epithelial cells in the upper respiratory tract of human (i.e. H1N1 and H3N2 viruses), but $\mathrm{H} 5 \mathrm{~N} 1$ viruses bind preferentially to $\mathrm{SA} \alpha 2,3 \mathrm{Gal}$ receptors, whereas it is predominantly located in the low respiratory tract of humans such as type II pneumocytes, alveolar macrophage, and non-ciliated cuboidal epithelial cells in terminal bronchioles. The result of this condition was the no replication of the virus due to the failure of the virus to recognize and attach to the receptors. Hence, this different distribution of the receptors might limit the $\mathrm{H} 5 \mathrm{~N} 1$ virus to infect human easily, moreover through human-to-human transmission. Zoonotic transmission of H5N1 might only occur when the virus mutated and acquired the ability to recognized SA 2 2,6Gal receptors besides SA $\alpha 2,3 \mathrm{Gal}$ receptors (Shinya et al., 2006; De Graaf and Fouchier, 2014).

The negative result might also be the cause of the small number of exposures or contact with the virus. Even though poultry workers often make a contact with the dead or infected chicken or more intensive poultry exposure, and are expected to have a higher risk of infection due to the lack of preventive measures and healthy environment, it does not mean that the poultry workers must have positive antibody against Avian Influenza subtype H5 (Indriani et al., 2010; Huo et al., 
2012). besides poultry workers that are prone to AI infection, others are people who visit the wet market. However, the people do not have constant exposure or direct contact with the infected poultry. Despite of that, a lot of AI-infected cases of people who visit the wet market were acute and fatal (To et al., 2012). This might happen when the people were exposed to a high amount of virus, but did not have a good body condition, which led to a bad immune response. Avian influenza A (H5N1) in humans differs in multiple ways from the influenza as a human virus, including the routes of transmission, clinical severity, pathogenesis, and response to treatment (Kumar et al., 2018).

The result of negative inhibition test occurred is the $\mathrm{HI}$ reference reagent as antigen was not antigenetically related to the serum (Kumar et al., 2018). Avian Influenza virus is an RNA virus which can easily mutate. Therefore, there was a possibility where the virus was mutating into a new form and structure. The serums which the researcher used were also mostly from the poultry workers at Larangan traditional market in which the majority of the tenants sell chicken, while the antigen for this research's HI assay was using antigen originated from the duck. Furthermore, the clade of the Avian Influenza subtype H5 antigen used was clade 2.3.2, while the highest cumulative number of avian-to-human transmission for H5NI cases and death in Indonesia was caused by Avian Influenza A subtype H5 clade 2.1.3 (Yupiana et al., 2010). These differences between species and the HA phylogeny also might be contributed to the negative result. Another reason that might also affect the results was that the antigen was taken from avian influenza outbreak in 2012. Therefore, there was a possibility that the virus circulating at Larangan traditional market in Sidoarjo was not the same as the one in the outbreak in 2012. Giving interventions directly in poultry sector was the most effective way to prevent human HPAI (Yupiana et al., 2010).

This study still had some limitations such as the lack of observations that can complement the results of research on the biological characteristics of the condition of poultry workers who contracted the AI virus, no microscopic observations of blood cells infected with the AI virus, and comparison of the seropositive clade type was not done. However, the results of the current study have provided additional information that poultry workers in the central traditional market of Sidoarjo were not infected with the Avian Influenza virus. Poultry workers in the market need to be given further precautions and safeguards against AI viruses. This research can be useful for veterinarians, practitioners, breeders, poultry workers, scientists, and livestock entrepreneurs as a prevention towards the poultries from spreading the AI virus.

\section{CONCLUSION}

Based on results of the research, it can be concluded that the percentage of seroprevalence of Avian Influenza (AI) virus subtype $\mathrm{H} 5$ among poultry workers at the central traditional market in Sidoarjo was 0\%, which means that none of the workers tested were contaminated with $\mathrm{AI}$ virus subtype $\mathrm{H} 5$.

\section{DECLARATION}

\section{Competing interests}

All authors have no conflict of interest to declares

\section{Author`s contribution}

Dina Novitasari and Chairul Anwar had similar roles in conduction and collection of samples and data, as well as analysis of data. Both authors checked and approved the final version of the manuscript.

\section{REFERENCES}

Al-Natour MQ, and Abo-Shehada MN (2005). Sero-prevalence of avian influenza among broiler-breeder flocks in Jordan. Preventive Veterinary Medicine, 70(1-2): 45-50. DOI: https://doi.org/10.1016/j.prevetmed.2005.02.009

Born S, Dörfel MJ, Hartjen P, Haschemi Yekani SA, Luecke J, Meutsch JK, Westphal JK, Birkelbach M, Köhnke R, Smeets R et al. (2019). A short-term plastic adherence incubation of the stromal vascular fraction leads to a predictable GMP-compliant cell-product. BioImpacts, 9(3): 161-172. DOI: https://doi.org/10.15171/bi.2019.20

De Graaf M, and Fouchier RAM (2014). Role of receptor binding specificity in influenza $\mathrm{A}$ virus transmission and pathogenesis. EMBO Journal, 33(8): 823-841. DOI: https://doi.org/10.1002/embj.201387442

Dung TC, Dinh PN, Nam VS, Tan LM, Hang NLK, and Thanh LT (2014). Seroprevalence survey of avian influenza A (H5N1) among live poultry market workers in northern Vietnam, 2011. Western Pacific Surveillance and Response Journal, 5(4): 21. PMID: 25685601

Frederika E, Mareta A, Poetranto D, Wulandari L, Setyoningrum RA, and Setyowati LL (2013). Identification of influenza viruses in human and poultry in the area of larangan wet market sidoarjo-east java, Indonesia. Indonesian Journal of Tropical and Infecous Disease, 4(4): 30-34. DOI: http://dx.doi.org/10.20473/ijtid.v4i4.230

Gutiérrez R A, Naughtin MJ, Horm SV, San S, and Buchy P (2009). A(H5N1) Virus evolution in South East Asia. Viruses, $1(3)$ : $335-361 . \quad$ DOI: https://doi.org/10.3390/v1030335 
Huo X, Zu R, Qi X, Qin Y, Li L, and Tang F (2012). Seroprevalence of avian influenza A (H5N1) virus among poultry workers in Jiangsu Province, China: an observational study. BMC Infectious Diseases, 12: 93. DOI: https://doi.org/10.1186/1471-2334-12-93

Indriani R, Samaan G, Gultom A, Loth L, Indryani S, and Adjid $R$ (2010). Environmental sampling for avian influenza virus A (H5N1) in live-bird markets, Indonesia. Emerging Infectious Diseases, 16(12): 1889-1895. DOI: https://doi.org/10.3201/eid1612.100402

Kumar B, Asha K, and Khanna M (2018). The emerging influenza virus threat: status and new prospects for its therapy and control. Archives of Virology, 163: 831-844. DOI: https://doi.org/10.1007/s00705-018-3708-y

Lailirahmawati I (2015). Isolasi Dan Identifikasi Virus Ai (Avian Influenza) Subtipe H5 Pada Ayam Sakit Yang Diperdagangkan Pada Pasar Larangan Sidoarjo. Universitas Airlangga, Airlanga, Pp. 1-6. Available at: http://repository.unair.ac.id/21114/4/4.\%20BAB\%201\%20P ENDAHULUAN.pdf

Mohsin A (2016). A Manual for Selecting Sampling Techniques in Research. University of Karachi, Munich Personal RePEc Archive Publication, Munich, Pp. 9-14. Available at: https://mpra.ub.uni-muenchen.de/70218/1/

OIE (2014). Terrestrial manual. Avian Influenza, P. 4. Available at:

https://www.oie.int/fileadmin/Home/eng/Health standards/t ahm/3.03.04_AI.pdf

Poetranto ED, Yamaoka M, Nastri AM, Krisna LAW, Rahman MH, and Wulandari L (2011). An H5N1 highly pathogenic avian influenza virus isolated from a local tree sparrow in Indonesia. Microbiology and Immunology, 55(9): 666-672. DOI: https://doi.org/10.1111/j.1348-0421.2011.00361.x

Robert M, Ry D, Holle VB, Setiawaty V, Pangesti KNA, and Sedyaningsih E (2010). Seroprevalence of avian influenze A H5N1 among poultry farmers in rural Indonesia 2007. Southeast Asian Journal of Tropical and Medical Public Health, 41(5): 1095-1103. Available at: https://linkinghub.elsevier.com/retrieve/pii/S120197120800 $\underline{4633}$

Santhia K, Ramy A, Jayaningsih P, Samaan G, and Gde A (2009). Avian influenza A H5N1 infections in Bali province , Indonesia: a behavioral , virological and seroepidemiological study. Influenza Other Respiratory $\begin{array}{llll}\text { Viruses, } & 3 \text { 8 } & 81-89 . & \text { DOI: }\end{array}$ https://dx.doi.org/10.1111\%2Fj.1750-2659.2009.00069.x

Shinya K, Ebina M, Yamada S, Ono M, Kasai N, and Kawaoka Y (2006). Avian flu: influenza virus receptors in the human airway. Nature, 440(7083): 435. DOI: https://doi.org/10.1038/440435a

Takano R, Nidom CA, Kiso M, Muramoto Y, Yamada S, and Sakai-Tagawa Y (2009). Phylogenetic characterization of
H5N1 avian influenza viruses isolated in Indonesia from 2003-2007. Virology, 390(1): 13-21. DOI: https://doi.org/10.1016/j.virol.2009.04.024

To KKW, Ng KHL, Que TL, Chan JMC, Tsang KY, Tsang AKL Chen H, and Yuen KY (2012). Avian influenza A H5N1 virus: a continuous threat to humans. Emerging Microbes \& Infections, $1(9)$ : e25. https://doi.org/10.1038/emi.2012.24

Wang G, Zhang,T, Li X, Jiang Z, Jiang Q, Chen Q, Tu X, Chen Z, Chang J, Li L et al. (2014). Serological evidence of H7, $\mathrm{H} 5$ and $\mathrm{H} 9$ avian influenza virus co-infection among herons in a city park in Jiangxi, China. Scientific Reports, 4: 6345. DOI: https://doi.org/10.1038/srep06345

Wang L, and Alexander CA (2021). COVID-19 compared with other viral diseases: novelties, progress, and challenges. Electronic Journal of General Medicine, 18(1): 265. DOI https://doi.org/10.29333/ejgm/8575

Wang TT, Parides MK, and Palese P (2012). Seroevidence for H5N1 influenza infections in humans: meta-analysis. Science, 335(6075): 1463. Availble at: https://doi.org/10.1126/science. 1218888

WHO (2013). Laboratory procedures. Serological detection of avian influenza A (H7N9) virus infections by modified horse red blood cells haemagglutination-inhibition assay. 20 December 2013- Geneva: WHO, pp. 1-12 Availble at: https://www.who.int/influenza/gisrs_laboratory/cnic_serolo gical diagnosis hai a h7n9 20131220.pdf

WHO (2014). Antigenic and genetic characteristics of zoonotic influenza viruses and development of candidate vaccine viruses for pandemic preparedness. Weekly Epidemiological Record, Available at: https://www.who.int/influenza/vaccines/virus/characteristics _virus_vaccines/en /

Wiyono A, Indriani R, Dharmayanti N, and dan Darminto RD (2004). Isolasi dan karakterisasi virus HPAI subtipe H5 dari ayam asal wabah di Indonesia. JITV, 9(3): 61-71. Available at:

http://repository.pertanian.go.id/bitstream/handle/12345678 9/3147/Isolation\%20and\%20characterization\%20of\%20viru s\%20of\%20highly\%20pathogenic\%20avian\%20influenza\% 20H5\%20subtype $\% 20$ of $\% 20$ chicken $\% 20$ from $\% 20$ outbreaks $\% 20 \mathrm{in} \% 20$ Indonesia.pdf? sequence $=1 \&$ is Allowed $=\mathrm{y}$

Xu C, Dong L, Xin L, Lan Y, Chen Y, and Yang L (2009). Human avian influenza A (H5N1) virus infection in China. Science in China Series C: Life Sciences, 52(5): 407-411. DOI: https://doi.org/10.1007/s11427-009-0067-7

Yupiana Y, Vlas SJ De, Adnan NM, and Hendrik J (2010). Risk factors of poultry outbreaks and human cases of $\mathrm{H} 5 \mathrm{~N} 1$ avian influenza virus infection in West Java province, Indonesia. International Journal of Infectious Diseases, 14(9): $\quad 800-805 . \quad$ DOI: http://dx.doi.org/10.1016/j.ijid.2010.03.014 